\title{
PENINGKATAN HASIL BELAJAR PENDIDIKAN \\ KEWARGANEGARAAN MELALUI METODE ROLE PLAYING \\ (Penelitian Tindakan Pada Siswa Kelas V SD Islamiyah 6 Kota Ternate)
}

\section{Fachriah Djumati}

Program Studi Pendidikan Sekolah Dasar. Universitas Negeri Jakarta FachriahDjumati43@gmail.com

\begin{abstract}
Abstrak
Salah satu masalah yang dihadapi dunia pendidikan di Indonesia saat ini adalah menyangkut lemahnya proses pembelajaran. pada proses pembelajaran, siswa kurang didorong untuk mengembangkan kemampuan berpikir sehingga hasil belajar yang dicapai masih rendah. Metode Role Playing dapat membantu siswa mengembangkan pengetahuan dan daya aktualisasinya dalam memahami materi pembelajaran Pendidikan Kewarganegaraan melalui penelitian tindakan (action research). Penelitian ini bertujuan mengetahui hasil belajar PKn pada siswa kelas V SD Islamiyah 6 Kota Ternate dapat ditingkatkan melalui metode role playing dan cara meningkatkan hasil belajar PKn melalui metode role playing pada Siswa Kelas V SD Islamiyah 6 Kota Ternate.

Penelitian ini merupakan penelitian tindakan yang dilakukan sebagai upaya perbaikan suatu praktek pendidikan pembelajaran di kelas secara profesional. Penelitian ini dilakukan di SD Islamiyah 6 Kota Ternate, pada siswa Kelas V yang berjumlah sebanyak 35 orang siswa pada tahun ajaran 2011/2012. Penelitian ini terdiri dari empat tahapan Perencanaan, pelaksanaan tindakan, observasi, dan refleksi. Kriteria keberhasilan tindakan dapat dilihat dari dua yaitu kriteria guru dan siswa. Proses pembelajaran yang dilakukan oleh guru harus mencapai $100 \%$ (mastery learning) dan $80 \%$ siswa harus mencapai KKM yang ditetapkan sekolah pada mata pelajaran PKn.

Hasil penelitian menunjukkan bahwa pada siklus I data hasil observasi pencapaian guru dalam pembelajaran role playing presentasi intrumen non tes siklus I pertemuan kesatu 66\% siswa dapat mencapai KKM sedangkan pertemuan kedua siswa yang mencapai kelulusan KKM adalah 77\%, sehingga penelitian dilanjutkan ke siklus-II. Pada siklus IIdata hasil observasi pencapaian guru dalam pembelajaran role playing meningkat. Pada pertemuan pertama siswa yang mencapai KKM adalah $88 \%$ sedangkan pada pertemuan kedua seluruh siswa mencapai KKM atau $100 \%$ berhasil. Dengan pencapaian nilai tersebut maka penelitian sudah mencapai target yang di tentukan yaitu $100 \%$. Oleh karna itu penelitian tidak dilanjutkan ke siklus berikutnya yaitu siklus III. Metode pembelajaran Role Playing sangat baik jika dilaksanakan di setiap sekolah karna dapat membuka wawasan siswa dan membuat siswa lebih aktif serta berani untuk mengungkapkan berbagai hal yang berkaitan dengan pembelajaran.
\end{abstract}

Kata kunci: Role Playing, Pembelajaran, Pendidikan Kewarganegaraan. 


\section{PENDAHULUAN}

Permasalahan pendidikan di Indonesia saat ini adalah menyangkut lemahnya proses pembelajaran. Pada proses pembelajaran, siswa kurang didorong untuk mengembangkan kemampuan berpikir sehingga hasil belajar yang dicapai masih rendah. Proses pembelajaran di dalam kelas lebih banyak diarahkan pada kemampuan untuk menghafal informasi. Otak siswa dipaksa untuk mengingat dan menimbun berbagai informasi tanpa dituntut untuk memahami informasi yang diingat itu untuk menghubungkannya dengan kehidupan sehari-hari. Akibatnya, ketika siswa lulus dari sekolah mereka pintar secara teoretis tetapi miskin dalam aplikasi, dan hal ini juga berlaku pada semua mata pelajaran. Pendidikan kewarganegaraan tidak hanya menuntut hafalan, tetapi mengajarkan untuk lebih kritis dan peka terhadap kondisi sosial dalam kehidupan sehari-hari. Zainul (2008) menyatakan bahwa pendidikan Kewarganegaraan dapat diartikan sebagai usaha sadar untuk menyiapkan peserta didik agar pada masa datang dapat menjadi pemimpin yang mempunyai kecintaan, kesetiaan, serta keberanian untuk membela bangsa dan tanah air melalui bidang profesinya masing-masing.

Permasalahan lain yang dikhawatirkan adalah terbukanya akses global melalui internet dan televisi. Kelalaian yang sering terjadi adalah kebebasan yang diberikan oleh orangtua terhadap anak saat berada di rumah. Gaya mengajar dan media belajar anak sangat mempengaruhi hasil belajar (De Porter \& Hermacki, 2001). Cara yang diajarkan orangtua maupun guru dalam mendidik siswa sangat mepengaruhi hasil atau output anak, baik secara moral maupun pengetahuannya. Pendidikan pada dasarnya memiliki tujuan menjadikan manusia yang berakal budi sebagaimana diamanatkan dalam Undang - undang No. 20 Tahun 2003 Tentang Sistem Pendidikan Nasional, pada Pasal 3 menyatakan bahwa: Pendidikan nasional berfungsi untuk mengembangkan kemampuan dan membentuk watak serta peradaban bangsa yang bermartabat dalam rangka mencerdaskan kehidupan bangsa, bertujuan untuk berkembangnya potensi peserta didik agar menjadi manusia yang beriman dan bertakwa kepada Tuhan Yang Maha Esa, berakhlak mulia, sehat, berilmu, cakap, kreatif, mandiri, dan menjadi warga negara yang demokratis serta bertanggung jawab.

Fungsi dan tujuan dari pendidikan juga dituangkan dalam maksud penerapan materi kewarganegaraan pada suatu jenjang pendidikan. Pencapaian fungsi pendidikan dapat tercapai melalui penerapan dan ketrampilan proses mengajar yang baik dari guru, salah satunya adalah penggunaan metode pembelajaran yang 
tepat di suatu jenjang pendidikan. Metode pembelajaran Role Playing adalah suatu cara penguasaan bahan-bahan pelajaran melalui pengembangan imajinasi dan penghayatan siswa dengan memerankan diri sebagai tokoh hidup atau benda mati. Metode role playing dikategorikan sebagai metode belajar yang berumpun kepada metode perilaku yang diterapkan dalam kegiatan pengembangan. Pada dasarnya ide utama dari role playing adalah untuk menjadi "sosok" individu yang diperankan untuk mendapatkan pemahaman tentang peran tersebut. Metode ini membantu peserta didik untuk menemukan makna pribadi dalam dunia sosial mereka dan memudahkan peserta didik berinteraksi melalui kerja kelompok (Miftahul, 2014). Mata pelajaran PKn membutuhkan metode yang dapat mengundang partisipasi peserta didik guna mengembangkan aspek kognitif peserta didik.

Hasil belajar mata pelajaran pendidikan kewarganegaraan rendah di Sekolah SD Islamiyah 6 Kota Ternate diduga disebabkan oleh variasi belajar yang kurang dan metode ajar yang cenderung konvensional. Metode pembelajaran role playingdiharapkan dapat meningkatkan hasil belajar siswa SD Islamiyah 6 Kota Ternate. mutu pembelajaran, menumbuhkan rasa sosial yang tinggi,dan dapat menghargai keputusan bersama seperti menghargai keputusan dalam lingkungan keluarga,sekolah,serta masyarakat. Penelitian ini bertujuan mengetahui hasil belajar PKn pada siswa kelas V SD Islamiyah 6 Kota Ternate dapat ditingkatkan melalui metode role playing dan cara meningkatkan hasil belajar PKn melalui metode role playing pada Siswa Kelas V SD Islamiyah 6 Kota Ternate.

\section{METODE PENELITIAN}

Penelitian ini merupakan penelitian tindakan yang dilakukan sebagai upaya perbaikan suatu praktek pendidikan pembelajaran di kelas secara profesional.Penelitian ini terdiri dari empat tahapan Perencanaan, pelaksanaan tindakan, observasi, dan refleksi.

\section{Waktu dan tempat penelitian}

Penelitian ini dilaksanakan di SD Islamiyah 6 Kota Ternate, pada siswa Kelas V yang berjumlah sebanyak 35 orang siswa pada bulan Mei sampai dengan Juni tahun 2012.

\section{Kehadiran peneliti}

Kehadiran peneliti di lapangan sangat menentukan terhadap kesuksesan penelitian, karena peneliti berusaha berinteraksi dengan subjek secara langsung dan 
meneliti secara alamiah, apa adanya (Lexy J. 2002) dalam (Ruwanti. 2009). Dalam penelitian tindakan ini peneliti bertindak sebagai pengajar (guru).

\section{Prosedur penelitian}

Metode penelitian yang digunakan dalam penelitian ini adalah penelitian tindakan (Action Research) atau penelitian tindakan yang dibentuk dalam bentuk spiral.Bentuk penelitian tindakan pada penelitian ini yaitu dengan memberikan suatu tindakan pada subjek yang diteliti dengan menggunakan metode Role Playing. Terdapat empat tahapan yang digunakan dalam penelitian ini yaitu: (1) Perencanaan tindakan yaitu peneliti bersama observer pendamping (secara kolaboratif) merumuskan dan mempersiapkan: rencana jadwal pelaksanaan tindakan, rencana pelaksanaan pembelajaran, materi/bahan pelajaran sesuai dengan pokok bahasan, Lembar Kerja Siswa, lembar penilaian, instrumen hasil belajar PKn, dan mempersiapkan kelengkapan lain yang diperlukan dalam rangka analisis data; (2) Pelaksanaan tindakan, yaitu Pelaksanaan tindakan pada dasarnya disesuaikan dengan setting tindakan yang telah ditetapkan dalam rencana pelaksanaan pembelajaran (RPP). Pelaksanaan tindakan rencananya dilakukan dalam tiga siklus (siklus I, siklus II dan siklus III), tiap siklus dengan alokasi waktu 60 menit ( 2 x 30 menit) sesuai dengan program tahunan yang ditetapkan sekolah; (3) Pelaksanaan observasi yaitu peneliti bersama observer pendamping untuk melakukan pengamatan terhadap aktivitas proses belajar siswa. Observasi tersebut dilakukan untuk mengenali, merekam dan mengumpulkan data dari setiap indikator mengenai unjuk kerja siswa dalam proses belajar kelompok selama berlangsungnya kegiatan pemecahan masalah terhadap peningkatan hasil belajar PKn dengan menggunakan metode Role Playing; (4) Refleksi merupakan kegiatan analisis sintesis, interpretasi dan eksplanasi/penjelasan terhadap semua data atau informasi yang dikumpulkan dari penelitian tindakan yang dilaksanakan. Data yang telah terkumpul kemudian ditindaklanjuti dengan melakukan analisis dan diinterpretasi, sehingga dapat diketahui akan hasil dari pelaksanaan tindakan yang dilakukan.

\section{Kriteria keberhasilan tindakan}

Kriteria keberhasilan tindakan ini dapat dilihat dari dua segi, yaitu yang pertama dari segi guru, proses pembelajaran yang dilakukan oleh guru harus mencapai $100 \%$ (mastery learning) dan yang kedua adalah dari segi siswa, dari segi siswa $80 \%$ dari siswa yang ada mencapai skor 70 sesuai dengan Kriteria Ketuntasan Minimum (KKM) yang telah ditetapkan oleh sekolah. Bila kedua kriteria di atas telah tercapai, maka penelitian dihentikan dan berarti ketentuan yang diharapkan telah tercapai. Indikator keberhasilan tindakan yang dilakukan merupakan keberhasilan proses, dimana prinsip belajar tuntas yang menjadi 
prioritas utama Data hasil pengamatan dianalisis secara kualitatif. Dengan menggunakan Rumus:

$$
P=\frac{T l}{N} \times 100 \%
$$

Keteranagan:

$$
\begin{aligned}
& \mathrm{P}=\text { persentase siswa yang tuntas belajar } \\
& \mathrm{n}=\text { banyak siswa yang tuntas belajar } \\
& \mathrm{N}=\text { banyak siswa keseluruhan }
\end{aligned}
$$

Kriteria hasil penelitian tentang pendidikan kewarganegaraan ditetapkan sebagai berikut (Corebima, dkk. 2010).

Tabel 1. Kriteria Nilai

\begin{tabular}{|r|c|c|}
\hline No & Nilai & Kriteria \\
\hline 1 & $91-100$ & Baik sekali \\
\hline 2 & $81-90$ & Baik \\
\hline 3 & $71-80$ & Cukup \\
\hline 4 & $61-70$ & Kurang \\
\hline 5 & $<60$ & Gagal \\
\hline
\end{tabular}

\section{HASIL DAN PEMBAHASAN}

\section{A. Hasil}

1. Analisis Data Observasi Tindakan Pembelajaran Kemampuan Memahami Keputusan Bersama dengan metode role playing.

Instrumen non tes berupa data observasi tindakan ini diperoleh dari lembar instrumen observasi tindakan yang diisi oleh observer. Hasil analisis data observasi tindakan Peneliti dalam pembelajaran Kemampuan Memahami Keputusan Bersama dengan menggunakan metode role playing pada siklus I, dapat dilihat pada tabel berikut. 
Tabel 2 : Data hasil observasi pencapaian guru dalam pembelajaran role playing

\begin{tabular}{|c|c|c|c|c|}
\hline No & \multirow{2}{*}{ Jenis Data } & \multicolumn{2}{|c|}{ Siklus } & $\begin{array}{c}\text { Skor } \\
\text { Maksimal }\end{array}$ \\
\cline { 3 - 4 } & Pertemuan I & Pertemuan II & 18 \\
\hline 2 & $\begin{array}{c}\text { Skor insrumen } \\
\text { non tes }\end{array}$ & 12 & 14 & $100 \%$ \\
\hline & $\begin{array}{c}\text { Persentase } \\
\text { instrumen non } \\
\text { tes }\end{array}$ & $66 \%$ & $77 \%$ & \\
\hline
\end{tabular}

Data hasil observasi guru dalam pembelajaran kemampuan Memahami Keputusan Bersama pada siklus I di atas pada pertemuan I baru tercapai $66 \%$ dan pada pertemuan keduanya perlakuan guru dalam pembelajaran dengan metode role playing meningkat menjadi $77 \%$. Selanjutnya tindakan peneliti dalam siklus berikutnya dengan menggunakan metode role playing dalam pembelajaran kemamapuan memahami keputusan bersama dapat dilihat hasilnya pada tabel di bawah ini;

Tabel 3. Pencapaian guru dalam pembelajaran dengan metode role playing siklus II

\begin{tabular}{|c|c|c|c|c|}
\hline No & \multirow{2}{*}{ Jenis Data } & \multicolumn{2}{|c|}{ Siklus } & $\begin{array}{c}\text { Skor } \\
\text { Maksimal }\end{array}$ \\
\cline { 3 - 4 } & Pertemuan I & Pertemuan II & 18 \\
\hline 2 & $\begin{array}{c}\text { Skor insrumen } \\
\text { non tes }\end{array}$ & 16 & 18 & $100 \%$ \\
\hline $\begin{array}{c}\text { Persentase } \\
\text { instrumen non } \\
\text { tes }\end{array}$ & $88 \%$ & $100 \%$ & \\
\hline
\end{tabular}

Data yang disajikan di atas menggambarkan pencapaian guru dalam pembelajaran kemampuan memahami keputusan bersama dengan metode role playing menunjukkan hasil yang seperti diharapkan. Hasil di atas pada pertemuan I siklus II yang disajikan adalah hasil pencapaian pertemuan I $88 \%$ dan meningkat pada pertemuan II mencapat target yang diharapkan $100 \%$. Dengan demikian pada pertemuan kedua ini peneliti sudah mencapai target dalam melaksanakan tindakan pembelajaran kemampuan memahami keputusan bersama dengan metode role playing. Selanjutnya, data hasil observasi siswa dalam pembelajaran role playing dapat dilihat pada grafik berikut ini; 


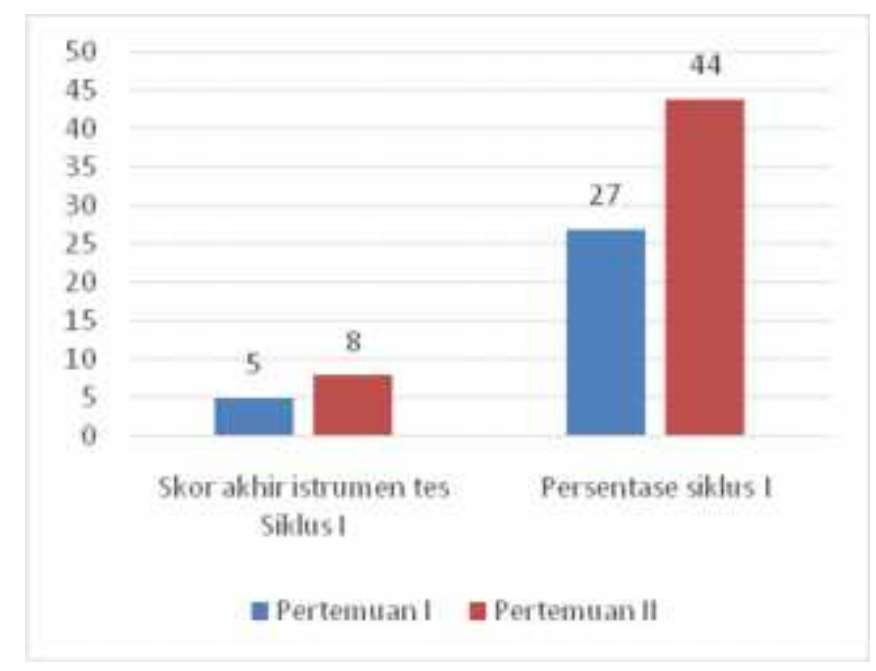

Grafik 1. Grafik hasil instrumen non tes Menghargai Keputusan Bersama siklus I

Seperti tampak pada grafik hasil instrumen non tes pada siklus I, pada awal pertemuan, masih terdapat banyak kekurangan sehingga hasil instrumen non tes yang diperoleh baru mencapai angka $27 \%$, pada pertemuan kedua walaupun terdapat peningkatan menjadi $44 \%$. Angka ini belum mencapai target yang diinginkan yaitu $100 \%$, sehingga peneitian dilanjutkan pada siklus II. Pada siklus II, berdasarkan instrumen observasi tindakan yang diisi oleh observer, diperoleh peningkatan pada proses karena peneliti berusaha memperbaiki kekurangan yang tampak pada siklus I. Data tersebut dapat disajikan dalam bentuk grafik sebagai berikut:

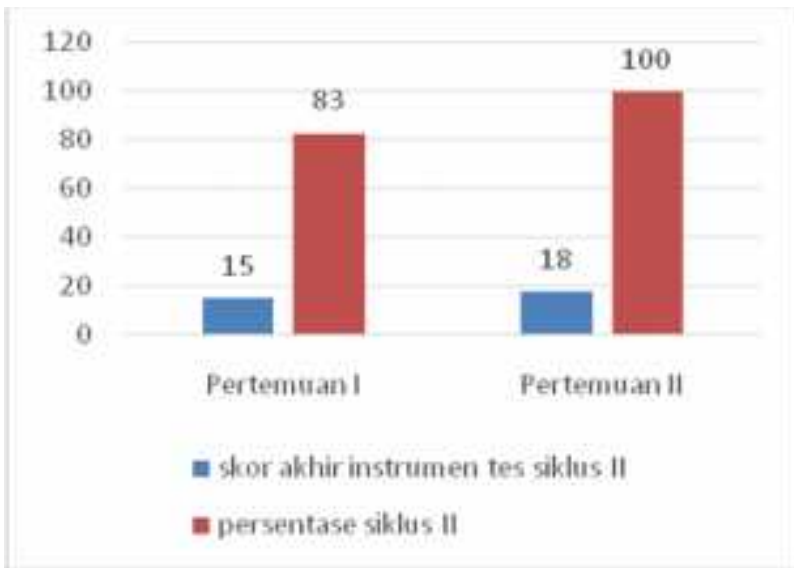

Grafik 2. Grafik hasil instrumen non tes siklus II 
Berdasarkan tabel dan grafik yang memperlihatkan hasil instrumen non tes pada siklus II, maka diperoleh peningkatan yang signifikan dari siklus I sehingga pada siklus II ini telah mencapai target yang diinginkan, yaitu $100 \%$. Peningkatan sudah memadai sebaga hasil perbaikan yang dilakukan berdasarkan kekurangankekurangan yang terjadi pada siklus I, maka proses tindakan pada siklus II ini telah mencapai target yang diinginkan. Karena itu tindakan pada siklus II ini peneliti dan kolaborator berkordinasi untuk mengakhiri tindakan pada siklus II saja. Untuk melihat peningkatan secara signifikan dari siklus I dan siklus II, maka dibawah ini disajikan data sebagai berikut:

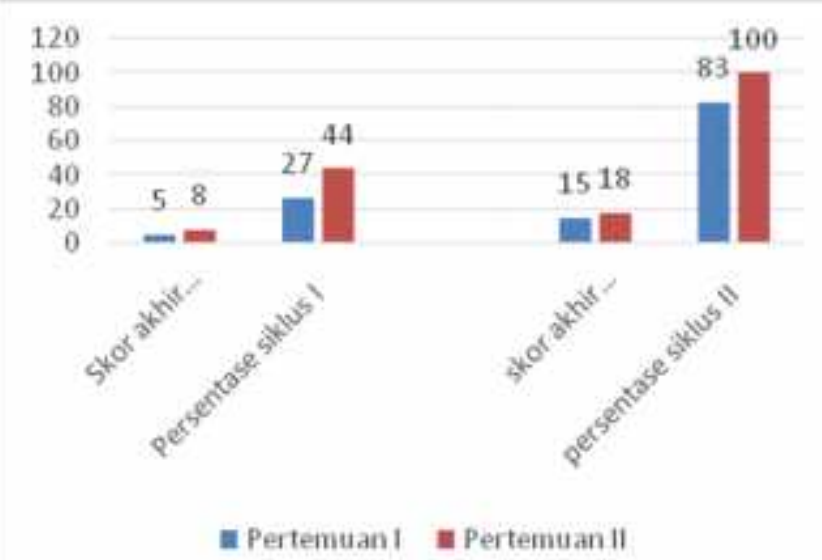

Grafik 3 : Rekapitulasi intrumen non tes menghargai keputusan bersama.

\section{Analisis Data Instrumen Tes Kemampuan Hasil Belajar Menghargai Keputusan Bersama}

Data ini diperoleh dari hasil tes kemampuan menghargai keputusan bersama setelah dilaksanakannya tindakan. Peneliti melakukan penilaian terhadap kemampuan menghargai keputusan bersama siswa yang diukur berdasarkan kemampuan memahami pertanyaan. Target yang ingin dicapai dalam penelitian ini adalah $86 \%$ atau 30 siswa dari jumlah seluruh siswa kelas V SD Islamiyah 6 yakni 30 siswa. 
Tabel 4. Data hasil instrumen tes kemampuan menghargai keputusan bersama siklus I.

\begin{tabular}{|c|c|c|c|}
\hline No. & $\begin{array}{c}\text { Pencapaian } \\
\text { hasil tes }\end{array}$ & $\begin{array}{c}\text { Jumlah } \\
\text { siswa }\end{array}$ & Persentase \\
\hline 1. & $50-59$ & 15 & $50 \%$ \\
\hline 2. & $60-69$ & 9 & $30 \%$ \\
\hline 3. & $70-79$ & 5 & $16 \%$ \\
\hline 4. & $80-89$ & 1 & $0,3 \%$ \\
\hline 5. & $90-100$ & - & - \\
\hline
\end{tabular}

Dari hasil tes kemampuan siswa menghargai keputusan bersama siklus I di atas dapat diketahui bahwa terdapat 24 siswa yang mendapat nilainya di bawah KKM mata pelajaran PKn yaitu 70, dan siswa yang mencapai KKM PKn baru 6 orang. Selanjunya bisa dilihat perkembangannya pada hasil tes kemampuan menghargai keputusan bersama pada siklus berikutnya yaitu siklus II di bawah ini.

Tabel 5. Data hasil Tes Menghargai Keputusan Bersama siklus II

\begin{tabular}{|c|c|c|c|}
\hline No. & $\begin{array}{c}\text { Pencapaian } \\
\text { hasil tes }\end{array}$ & $\begin{array}{c}\text { Jumlah } \\
\text { siswa }\end{array}$ & Persentase \\
\hline 1. & $50-59$ & - & - \\
\hline 2. & $60-69$ & 3 & $10 \%$ \\
\hline 3. & $70-79$ & 18 & $60 \%$ \\
\hline 4. & $80-89$ & 7 & $23 \%$ \\
\hline 5. & $90-100$ & 2 & $0,6 \%$ \\
\hline
\end{tabular}

\section{Analisis Data Hasil Tes Berdasarkan Ranah Kognitif dan Afektif.}

Dari data hasil tes siklus I dapat dianalisis juga berdasarkan ranah kognitif dan afektif yaitu pada ranah kognitif C1 10 siswa atau 30\%, C2 8 siswa atau 26 $\%$, C3 6 siswa atau $20 \%$ dan A1 7 siswa atau $23 \%$. Data pada tabel di atas disajikan pada grafik di bawah ini. 




Grafik 5 : Hasil tes setiap ranah Siklus I

Data tersebut di atas diketahui bahwa ranah kognitif dan afektif belum mencapai hasil yang diharapkan, sehingga dilanjutkan pada siklus II. Data pada tabel di atas dapat disajikan pada tabel berikut ini;

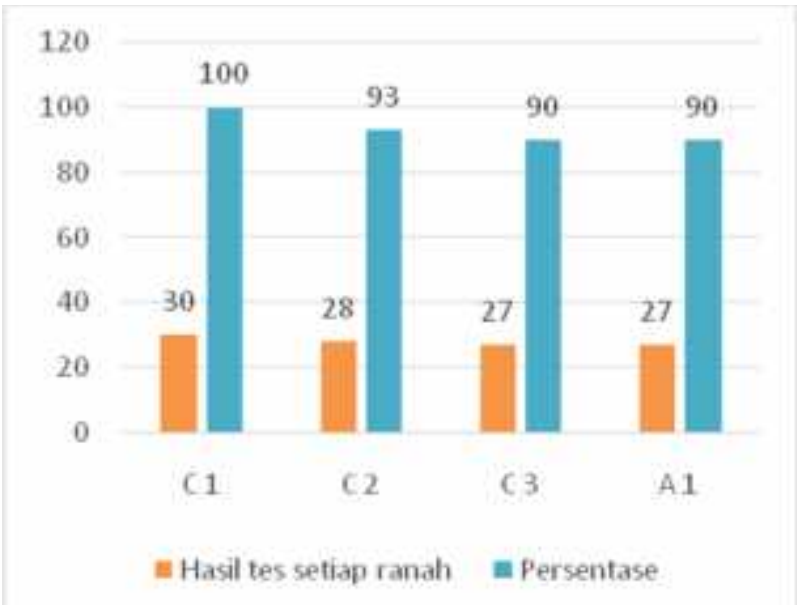

Grafik 6 : Hasil Tes berdasarkan ranah kognitif dan afektif siklus II

Dari grafik di atas dapat diketahui bahwa nilai yang dicapai oleh siswa pada kemampuan menghargai keputusan bersama siswa pada siklus II, baik hasil tes secara keseluruhan dan hasil berdasarkan ranah kognitif dan afektif sudah mencapai KKM mata pelajaran PKn yang seperti diharapkan, sehingga penelitian tindakan ini tidak dilanjutkan lagi pada siklus berikutnya. 


\section{B. Pembahasan}

Dilihat dari hasil analisis data selama tindakan mulai siklus I sampai siklus II terlihat adanya penngkatan dari semua data yang diambil. Data tes berupa skor kemampuan menghargai keputusan bersama siswa mengalami peningkatan, dan hasil analisisnya dapat dilihat pada perkembangan hasil yang dicapai mulai dari siklus I meliputi data hasil observasi yang diperoleh dari lembar observasi tindakan menunjukkan hasil pada siklus I yakni pertemuan pertama pencapaian guru dalam pembelajaran role playing $66 \%$ dan kemudian meningkat pada pertemuan kedua menjadi $77 \%$. Peningkatan ini menunjukkan bahwa metode role playing yang diterapkan pada proses pembelajaran ini dapat membuat perubahan yang cukup bagi keberhasilan guru dalam proses pembelajarannya.

Selanjutnya pada hasil instrumen tes siklus I kemampuan memahami keputusan bersama melalui metode role playing yaitu 15 siswa atau $50 \%$ mendapat nilai antara 50-59, 9 siswa atau $30 \%$ mendapat nilai 60-69, 5 siswa atau $16 \%$ mendapat nilai 70-79, dan 1 siswa atau 0,3\% mencapai 80-89.

Hasil ini masih menunjukan bahwa keberhasilan siswa dalam mencapai KKM mata pelajaran Pkn masih jauh dari harapan.Untuk meningkatkan kemampuan memahami keputusan bersama melalui metode role playing, maka siswa dilatih untuk lebih aktif dan menghayati pemeranannya dalam permainan role playing tentang memahami keputusan bersama. Kegiatan ini dilakukan pada setiap kegiatan awal kegiatan inti dalam pembelajaran role playing. Selain itu, siswa dilatih untuk berdiskusi dengan berkelompoknya dan bekerja sama untuk saling memperbaiki pemerananya dalam permainan tersebut. Pada tindakan siklus I ini siswa belum terbiasa bermain peran dan berdiskusi dengan teman yang lainnya dalam satu kelompok sehingga mereka kelihatannya masih bingung. Dengan demikian hasil dari proses pembelajaran dan hasil tes pada siklus I ini masih jauh dari target yang diharapkan pada penelitian ini.

Selanjutnya pada siklus II, siswa diberikan motivasi dalam dalam meningkatkan pemeranannya dalam permainan role playing dan memberikan latihan yang maksimal terhadap masing-masing pemeran. Setiap kelompok di berikan motivasi hadiah berupa buku bacaan dan alat-alat tulis bagi kelompok yang tampil lebih bagus dari siklus sebelumnya yakni siklus I. Dengan adanya pemberian hadiah ini siswa berlomba-lomba untuk tampil lebih bagus dan penuh semangat. Dengan demikian hasil yang diperoleh pada siklus II menjadi meningkat. Seperti data yang diperoleh pada instrumen non tes siklus II untuk peneliti dalam pembelajaran role playing meningkat menjadi $88 \%$ pertemuan 
pertama siklus II dan meningkat lagi menjadi 100 pada pertemuan kedua siklus II. Selanjutnya hasil observasi siswa dalam pembelajaran role playing meningkat pada pertemuan pertama siklus II yaitu mencapai $83 \%$ dan pada pertemuan keduanya meningkat menjadi $100 \%$.

Hasil yang diperoleh siswa semakin menigkat dari siklus sebelumnya, yakni nilai yang diperoleh dalam pembelajaran kemampuan memahami keputusan bersama melalui metode role playing pada siklus kedua ini membuahkankan hasil yang cukup signifikan dari siklus I. Hasil tersebut dapat disimak dari data berikut: 3 siswa mencapai nilai 60-63, 18 siswa mencapai 70-79, 7 siswa mencapai 80-89, dan 2 siswa mencapai 90-100. Selanjutnya, pencapaian pada ranah kognitif C1 30 Siswa, C2 28 siswa, C3 27 siswa dan A1 27 siswa. Dengan demikian hasil yang telah meningkatsecara signifikan pada siklus kedua ini sebagaimana harapan peneliti telah tercapai, maka penelitian ini tidak dilanjutkan lagi karena telah mencapai hasil yang diharapkan. Namun terdapat 3 siswa harus diremedialkan karena mencapai nilai yang dicapai pada siklus II ini masih di bawah KKM.

\section{SIMPULAN}

Hasil belajar siswa dari siklus I dan siklus II meningkat secara signifikan. Hasil belajar siklus I belum mencapai KKM Mata Pelajaran PKn yang mencapai nilai 70. Hasil siklus I ini belum mencapai karena $80 \%$ siswa baru mencapai nilai di bawah 70. Kemudian perbaikan pembelajaran oleh peneliti dan mengaktifkan siswa dalam pembelajaran role playing pada siklus II barulah nilainya meningkat di atas 70 . Dari jumlah siswa 30 orang hanya 3 orang siswa yang diremedial. Hasil observasi menunjukkan bahwa simulasi tentang kemampuan memahami keputusan bersama dapat meningkatkan kemampuan siswa dalam memimpin rapat kelas, membuat keputusan yang dapat diterima oleh teman lainnya, mengaktifkan siswa dalam diskusi kelompok, menerima dan menghargai perbedaan pendapat, melakukan musyawarah untuk mencapai mufakat, meningkatkan rasa tanggung jawab terhadap tugas yang diembankan, meningkatkan persahabatan dan kerjasama yang baik antar sesama siswa dalam kelompok dan saling membantu untuk pelaksanaan hasil keputusan.

\section{DAFTAR PUSTAKA}

Arikunto, S. 2005. Prosedur Penelitian Suatu Pendekatan Praktek. Jakarta: Rineka Cipta. 
BSNP. 2006. Kurikulum Tingkat Satuan Pendidikan SD/MI. Jakarta: Departemen Pendidikan Nasional.

DePorter, B; \& Hernacki, M. 2000. Quantum Learning: Membiasakan Belajar Nyaman dan Menyenangkan. Bandung: Kaifa.

Corebima, D.A., Mas'ud, A., dan Sundari. 2010. Penelitian Tindakan Kelas, di Siapkan Untuk Guru dan Calon Guru. LepKhair. Ternate

Miftahul Huda. 2014. Model-Model Pengajaran dan Pembelajaran. Yogyakarta: Pustaka Belajar.

Zainul Ittihad Amin. 2008. Pendidikan Kewarganegaraan.Jakarta: Universitas Terbuka.

Ruwanti. 2009. Evaluasi pembelajaran, Modul Akta mengajar. UMM Press. 